\title{
Czesław Błaszak
}

\section{ODWIECZNOŚĆ - OKIEM PRZYRODNIKA, CZYLI MEANDRY FILOGENEZY ŚWIATA ZWIERZĄT}

Przedstawienie problemów filogenezy świata zwierząt na kilkunastu stronach jest praktycznie zadaniem niewykonalnym i dlatego ograniczę się $\mathrm{w}$ tych rozważaniach do momentów najważniejszych. Postaram się je przedstawić tak, aby były zrozumiałe (przynajmniej w części) dla humanisty, a jednocześnie nie były zbyt dużym uproszczeniem dla czytelnika będącego biologiem.

Filogeneza, jako rozwój rodowy żywych organizmów, obejmuje przebieg ewolucyjnego różnicowania (ich ontogenez - rozwojów osobniczych) oraz wyodrębnianie się nowych linii rozwojowych, a wymieranie innych. Graficznym przedstawieniem filogenezy jest drzewo filogenetyczne (ryc. 1).

Z filogenezą ściśle związana jest klasyfikacja, i dlatego mamy tak wiele różnych systematyk, ponieważ nie mamy pewnych danych dotyczących pochodzenia danej grupy zwierząt. Tak więc każda systematyka porządkująca świat zwierzęcy jest hipotezą opartą na danych filogenetycznych. Z zasadami systematyki organizmów są ściśle związane dwa terminy: monofiletyzm i polifiletyzm. Monofiletyzm to pochodzenie danej grupy systematycznej od wspólnego przodka, czyli z jednej linii rodowej. Pogląd ten, dominujący we współczesnej systematyce, jest podstawą tworzenia prawidłowych systematyk. W odróżnieniu od monofiletyzmu, polifiletyzm zakła- 
da powstanie danej grupy systematycznej nie z jednej, lecz z kilku linii wyjściowych, które ewoluowały zbieżnie (konwergencja rozwoju).

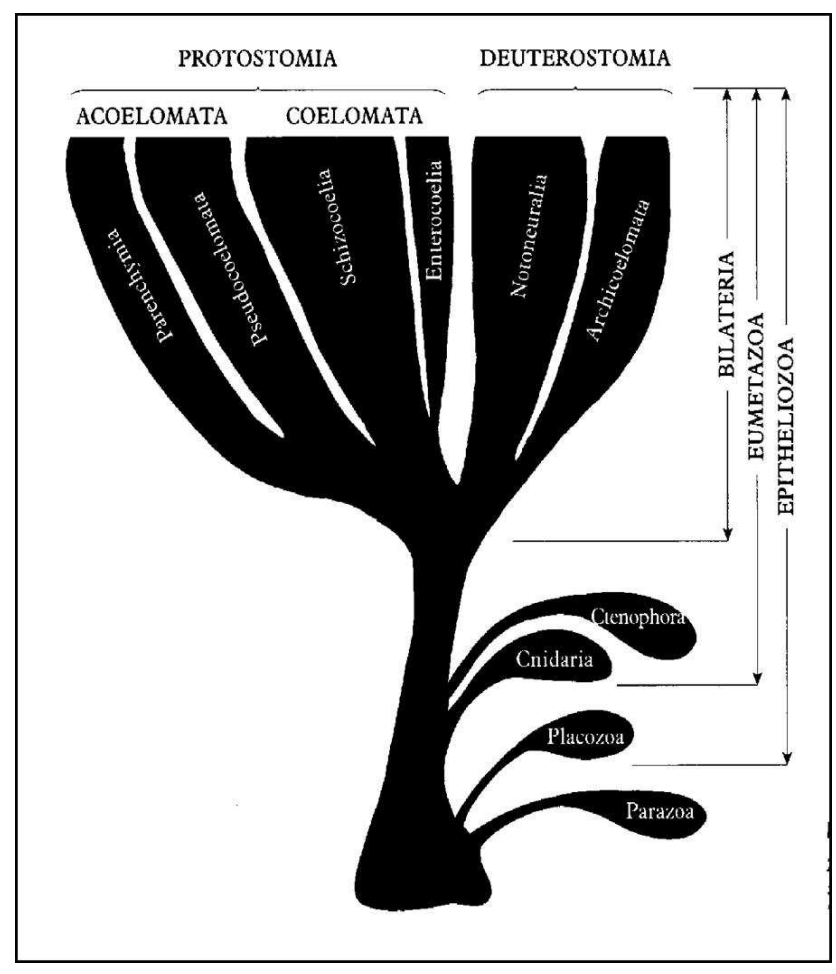

Ryc. 1. Drzewo filogenetyczne wielokomórkowców zwierzęcych - Metazoa z poziomami organizacji na podstawie hipotezy jam ciała ${ }^{1}$

Królestwo zwierząt (Animalia) razem z "pierwotniakami” (Protista), roślinami (Plantae) i grzybami (Fungi = Mycota) wchodzą w skład nadkrólestwa (cesarstwa) eukariontów (Eukaryota, Eukarya). Cechą charakterystyczną eukariontów jest morfologicznie wyróżnione jądro komórkowe z chromozomami, otoczone podwójną błoną lipidowo-białkową. Poza jądrem występują charakterystyczne organelle komórkowe: mitochondria, aparat Golgiego, plastydy, retikulum endoplazmatyczne i inne. Okazuje się, że są "pierwotniaki", które nie mają dwóch podstawowych organelli charakterystycznych dla każdej komórki eukariotycznej, a więc mitochondriów i aparatu Golgiego. Wchodzą one w skład domeny Excavata (ryc. 10). Należą do niej między innymi znane pasożyty człowieka z rodzaju rzęsistek - Trichomonas i lamblia

${ }^{1}$ Za: Cz. Błaszak, Zwierzęta - Animalia, w: Zoologia, t. I, cz. 1: „Bezkręgowce: nibytkankowce-pseudojamowce", red. Cz. Błaszak, Warszawa 2013. 
z rodzaju Giardia. Te wyjątki pokazują, jak w biologii trzeba uważać na sformułowania typu „zawsze” i „wszystkie”. Bo wydawać by się mogło, że niemożliwe, aby komórka eukariotyczna nie miała tak niezwykle ważnych organelli, jak mitochondria i aparat Golgiego, a jednak są wyjątki.

Dla celów tego tekstu zachowano królestwo „pierwotniaków” - Protista, które jest grupą sztuczną i składa się z wielu niezależnych od siebie domen. Istnieje wiele ciągle zmieniających się klasyfikacji tak zwanych pierwotniaków (organizmów składających się z jednej komórki). Jedną z popularnych i często używanych systematyk przedstawiam poniżej:

Domena: Amoebozoa

Domena: Excavata

Domena: Discicristata

Domena: Rhizaria

Domena: Stramenopiles

Domena: Alveolata

W tej klasyfikacji zwraca uwagę utworzenie sześciu domen. Uznając taki podział "pierwotniaków”, musimy automatycznie dla Eukaryota otworzyć wyższą jednostkę taksonomiczną, np. cesarstwo, aby mogło ono objąć wszystkie domeny organizmów eukariotycznych.

Wydawać by się mogło, że łatwo odróżnić poszczególne królestwa od siebie w cesarstwie Eukaryota. Spróbujmy więc zastanowić się, jakie cechy wyróżniają zwierzęta spośród innych organizmów eukariotycznych. Porównania dokonamy pomiędzy królestwami zwierząt, roślin i grzybów, pomijając domeny „pierwotniacze”.

1. Sposób odżywiania. W przeciwieństwie do autotroficznych (samożywnych) roślin, wszystkie zwierzęta są heterotroficzne (cudzożywne), podobnie jak i grzyby. Tutaj również mamy przykład użycia terminu „wszystkie zwierzęta", który nie w pełni odpowiada rzeczywistości, gdyż formy dorosłe morskich pierścienic z typu rurkoczułkowców (Pogonophora) nie mają przewodu pokarmowego, a zamiast niego trofosomę - narząd wypelniony licznymi komórkami zawierającymi symbiotyczne bakterie chemosyntetyzujące, czerpiące energię do syntezy związków organicznych na drodze utleniania siarki i jej zredukowanych związków lub z utleniania metanu. Wyprodukowane przez bakterie związki służą rurkoczułkowcom za pokarm. Tak więc dorosłe rurkoczułkowce, korzystając z symbiotycznych bakterii, są praktycznie chemoautotrofami (a więc są samożywne, podobnie jak rośliny będące fotoautotrofami) ${ }^{2}$.

2 J. Sicinski, Pierścienice - Annelida, w: Zoologia, t. I, cz. 2: „Bezkręgowce, wtórnojamowce (bez stawonogów", red. Cz. Błaszak, Warszawa 2013, s. 601-685. 
2. Brak ściany komórkowej. U roślin i większości grzybów występuje ściana komórkowa (u roślin - z celulozy, u grzybów - z chityny i jej pochodnych). Brak jej u zwierząt, lecz także brak u niektórych grzybów, np. w grupie skoczkowców - Chytridiomycetes.

3. Glikogen, jako materiał zapasowy, jest charakterystyczny dla zwierząt, ale występuje również u grzybów, a brak go u roślin. Wyżej wymienione cechy wyraźnie pokazują (ryc. 10, patrz: domena Opisthokonta), jak blisko grzybom do zwierząt. (rośliny znajdują się w zupełnie innej domenie: Archaeplastida). Dopiero ostatnia cecha wyraźnie oddzieli królestwo zwierząt od grzybów.

4. Układ mięśniowy i nerwowy. Są to cechy charakterystyczne tylko dla przedstawicieli królestwa zwierząt, a brak ich u organizmów innych królestw. Problem jednak $\mathrm{w}$ tym, że oba układy nie występują u wszystkich typów świata zwierząt. Brak ich mianowicie m.in. w takich typach zwierząt, jak gąbki (Porifera) czy płaskowce (Placozoa).

Nie ulega wątpliwości, że wymienione typy, u których brak układu mięśniowego i nerwowego, są wielokomórkowymi organizmami, które winny należeć do świata zwierząt. Jednakże przy braku typowo zwierzęcych układów (mięśniowego i nerwowego) trudno nazywać je zwierzętami. Przyjmuje się niekiedy zamiennie termin "wielokomórkowce zwierzęce” - Metazoa, zamiast „zwierzęta” - Animalia.

Stąd w niektórych systematykach (często amerykańskich) w cesarstwie Eukaryota przyjmuje się jako królestwo: wielokomórkowce zwierzęce - Metazoa, które dzieli się na następujące podkrólestwa: Gąbki (Porifera), płaskowce (Placozoa) i podkrólestwo: zwierzęta - Animalia.

Po tych uwagach dostrzegamy już pierwsze kłopoty ze zdefiniowaniem królestwa zwierząt.

Odnośnie do pochodzenia organizmów zwierzęcych aktualnie przeważają teorie monoenergidowego pochodzenia, które zakładają, że wielokomórkowce zwierzęce (Metazoa) pochodzą z kolonii dzielących się komórek (klony komórkowe).

Pochodzenie Metazoa przebiegałoby w trzech etapach:

1. Etap polimeryzacji organizmów jednokomórkowych (blastula);

2. Etap różnicowania, czyli dyferencjacji, a więc powstawania drugiego listka zarodkowego (gastrea, fagocytella, planula, placula);

3. Etap integracji wszystkich komórek w jednolity organizm.

Aktualnie przyjmowane są najczęściej trzy systemy filogenetyczne dotyczące pochodzenia poszczególnych grup świata zwierząt: hipoteza "jam ciała", hipoteza "ekdyzonu" i hipoteza "spiralia". 
Przyjęcie którejkolwiek hipotezy jest zawsze subiektywne. Co istotne, te systemy filogenetyczne różnią się w kwestii klasyfikacji świata zwierząt, i to niekiedy wyraźnie. Widać więc, że już na wstępnym etapie, przy przyjmowaniu konkretnego systemu filogenetycznego (np. mniej lub bardziej popularnego) stajemy „po czyjejś stronie”. W redagowanej przeze mnie Zoologii dałem czytelnikowi wybór, przedstawiając główne założenia wszystkich trzech hipotez (jest to jedyny podręcznik akademicki na świecie, który traktuje systematykę jako kwestię wyboru).

W niniejszym tekście rozważania dotyczące problemów filogenetycznych zostały oparte o hipotezę „jam ciała”.

Pierwszym problem przy dyskusji nad filogenezą królestwa zwierząt jest pytanie o monofiletyczność całego królestwa.

Pogląd o monofiletyczności zwierząt przeważa nad poglądem difiletyzmu, mówiącym o niezależnym pochodzeniu gąbek od pierwotniaków z grupy Choanoflagellata. Za monofiletycznościa przemawiają takie cechy, jak: podobna budowa ultrastrukturalna komórki monociliarnej, rozwój i struktura gamet oraz diploidalność. Również badania molekularne sekwencji 18S-rRNA wskazują na monofiletyczność, podobnie jak podobieństwo w budowie genu tworzącego kolagen u gąbek, szkarłupni i kręgowców. Pozakomórkowej macierzy nie powinno się uważać za cechę autapomorficzną dla zwierząt (a więc cechę nową, charakterystyczną tylko dla zwierząt), ponieważ brak jej u gąbek (Porifera) i płaskowców (Placozoa). Znów możemy zadać pytanie, dlaczego macierzy pozakomórkowej (niezwykle istotnej cechy $\mathrm{w}$ organizmie zwierzęcym) nie możemy uznawać za cechę autapomorficzną? Jest to odrzucanie à priori, kierujące się jedynie założeniem, że nie pasuje to do hipotezy monofiletyzmu świata zwierząt. O tym, że jest to dyskusyjne, niech świadczy systematyka przedstawiona powyżej, w której typy gąbki i płaskowce nie należą do podkrólestwa zwierząt, gdyż utworzono dla nich oddzielne podkrólestwa w obrębie wielokomórkowców zwierzęcych.

Za difiletycznym pochodzeniem królestwa zwierząt (typ: gąbki pochodziłyby od pierwotniaków z grupy Choanoflagellata) przemawia, oprócz występowania komórek kołnierzykowo-biczykowych (choanocytów), przede wszystkim brak tkanek $u$ gąbek. Igły szkieletowe gąbek znane są od prekambu i gąbki przez okres ponad 0,5 miliarda lat nie wykształciły żadnej tkanki (nawet nabłonkowej). Cechą charakterystyczną i, jak dotychczas uważano, wyłączną wśród wszystkich zwierząt jest występowanie u nibytkankowców choanocytów, czyli monociliarnych komórek kołnierzykowo-biczykowych, nawiązujących do pierwotniaków z grupy Choanoflagellata. Komórki kołnierzykowo-biczykowe stwierdzono również u wysoko zorga- 
nizowanych organizmów (Harrimania kupferi) z gromady jelitodysznych w typie: półstrunowców - Hemichordata. Jednocześnie trzeba wyraźnie powiedzieć, że nie wszystkie gąbki mają choanocyty, np. brak ich w rodzaju Azbestopluma. Tak więc komórki kołnierzykowo-biczykowe nie są tak mocną cechą, jak dotychczas zwykło się podawać. Cechą pierwotną nibytkankowców jest duża plastyczność komórek, polegająca na tym, że mogą one przejmować funkcje innych komórek (totipotencjalność). Brak jest u gąbek właściwych dla zwierząt listków zarodkowych. Niezwykle prymitywną cechą gąbek jest sposób odżywiania, charakterystyczny dla organizmów jednokomórkowych, czyli pierwotniaków. Choanocyty przy pomocy wici i kołnierzyka kierują cząstki organiczne ku powierzchni komórki, gdzie wypustki plazmatyczne wychwytują i przekazują je amebocytom (transport membranowy poprzez pinocytozę i fagocytozę), czyli amebocyty roznoszą pokarm do poszczególnych komórek. Pochodzenie gąbek jest niejasne, chociaż, jak już zaznaczyłem, najczęściej łączy się je z pierwotniakami z grupy Choanoflagellata. Jednak budowa witki choanocytów gąbek jest odmienna, gdyż jest ona zaopatrzona $\mathrm{w}$ odchodzące od mikrotubul centralnych tak zwane chorągiewki boczne. Położenia gąbek (jeśli przyjmiemy monofiletyzm świata zwierząt) należy się doszukiwać przy podstawie drzewa rodowego wszystkich Metazoa ( $w$ stadium gastrei, a więc $\mathrm{w}$ stadium organizmu dwuwarstwowego). Jednocześnie jednak są one na tyle odmienne od innych taksonów świata zwierzęcego, że pozwala to prawie z całą pewnością stwierdzić, że żadna dzisiaj żyjąca grupa świata zwierząt nie pochodzi od gąbek.

Brak związków filogenetycznych gąbek $\mathrm{z}$ aktualnie żyjącymi typami zwierząt każe w sposób ostrożny traktować monofiletyzm całego królestwa Metazoa, podobnie zresztą jak każe $\mathrm{z}$ dystansem patrzeć na monofiletyzm samych gąbek, gdyż obok poglądów monofiletycznych, występują także hipotezy, zgodnie z którymi u gąbek występuje również polfiletyzm.

Monofiletyzm świata zwierząt nie może być traktowany jako proces wyjaśniony i ostatecznie potwierdzony, gdyż badania molekularne wskazują wyraźnie na brak monofiletyzmu wewnątrz królestwa zwierząt, np. w olbrzymiej grupie filogenetycznej, jaką są tkankowce właściwe (Eumetazoa) organizmy, które mają dwie cechy charakterystyczne dla zwierząt: układ nerwowy i mięśniowy, czyli są właściwymi zwierzętami.

Dla ogólnego zorientowania się $\mathrm{w}$ zawiłościach systematyki zwierząt poniżej został podany ogólny zarys podziału.

Królestwo: wielokomórkowce zwierzęce - Metazoa

Podkrólestwo: nibytkankowce - Parazoa

Podkrólestwo: tkankowce - Epitheliozoa 
Naddział: płaskowce - Placozoa

Naddział: tkankowce właściwe - Eumetazoa

Dział: promieniste - Radiata

Dział: dwupromieniste - Biradiata

Dział: dwubocznie symetryczne - Bilateria

Poddział: pierwouste - Protostomia

Poddział: wtórouste - Deuterostomia

Przyjmując monofiletyzm świata zwierząt, można je podzielić na dwie wyraźnie różniące się grupy: nibytkankowce (Parazoa), z jednym typem gąbek (Porifera), i tkankowce (Epitheliozoa), których cechą charakterystyczną jest wytworzenie tkanek. Przy czym Epitheliozoa nie są zwartą filogenetycznie grupą, gdyż należą tu dwie jednostki różniące się wyraźnie, a mianowicie płaskowce (Placozoa) i tkankowce właściwe (Eumetazoa). U płaskowców brak jest m.in. komórek mięśniowych i nerwowych oraz macierzy pozakomórkowej, które to cechy występują u tkankowców właściwych (Eumetazoa).

Płaskowce to maleńka grupa mająca wykształconą jedynie tkankę nabłonkową. Cechą pierwotną płaskowców (Placozoa) jest najniższa zawartości DNA w jądrze spośród wszystkich zwierząt. Pozycja filogenetyczna płaskowców wśród wczesnych Metazoa jest przedmiotem wielu kontrowersji. Kompromisowa praca dotycząca analizy całego genomu rodzaju Trichoplax sugeruje, że płaskowce wyodrębniły się później niż gąbki, ale wcześniej niż parzydełkowce i dwubocznie symetryczne - Bilateria, a więc są najstarszymi żyjącymi przedstawicielami tkankowców.

Drugą grupą tkankowców, obejmującą wszystkie pozostałe typy świata zwierząt, są tkankowce właściwe - Eumetazoa, czyli właściwe zwierzęta. Ich cechą charakterystyczną jest występowanie tkanki mięśniowej i nerwowej, które są uważane, podobnie jak przewód pokarmowy, za homologiczne u wszystkich tkankowców właściwych. Cechami popierającymi tezę o monofiletyczności Eumetazoa są przebieg gastrulacji i wykształcenie dwóch pierwszych listków zarodkowych (ekto- i entodermy). Badania molekularne nad $28 \mathrm{~S}$ r-RNA nie potwierdzają monofiletyzmu tkankowców właściwych, gdyż wskazują, że Bilateria (dwubocznie symetryczne) oddzieliły się wcześniej niż parzydełkowce (Cnidaria) i żebropławy (Ctenophora). Rodzi się pytanie - oddzieliły się wcześniej od czegoś innego czy od wspólnego pnia (patrz ryc. 1)?

Wytworzenie tkanki nabłonkowej i odgraniczenie wnętrza organizmu od środowiska zewnętrznego było decydującym momentem w powstawaniu i ewolucji układu nerwowego i mięśniowego, a więc cech typowo zwierzęcych. Dominuje teza, że zarówno miocyty, jak i neurony powstawały 
w nabłonku, który początkowo był neuroepithelem (nabłonkiem nerwowym) i myoepithelem (nabłonkiem mięśniowym).

Eumetazoa można podzielić, ze względu na symetrię, na promieniste Radiata (obejmującą tylko jeden typ parzydełkowców - Cnidaria), dwupromieniste - Biradiata (również z jednym małym typem żebropławów - Ctenophora) i dwubocznie symetryczne - Bilateria (ryc. 1).

Warto zaznaczyć, że Cnidaria tworzą zamkniętą gałąź rodową. Nie są grupą wyjściową dla jakiegokolwiek typu zwierząt dwubocznych, a tym bardziej dla Bilateria jako całości. Utworzenie dla Cnidaria odrębnego naddziału Radiata jest więc całkowicie uprawnione nie tylko ze względu na cechy ich budowy, ale przede wszystkim ze względu na historię fauny zwierząt wielokomórkowych. Podobnie sprawa wygląda z dwupromienistymi.

Tak więc dwubocznie symetryczne (Bilateria) są główną grupą skupiającą wszystkie pozostałe typy świata zwierząt. Pojawienie się symetrii dwubocznej było związane z aktywnym poruszaniem się, co doprowadziło do polaryzacji ciała (przód, tył, strona grzbietowa, strona brzuszna). Oprócz otworu gębowego, pojawił się otwór odbytowy, co spowodowało zróżnicowanie się przewodu pokarmowego nie tylko pod względem anatomicznym, ale przede wszystkim fizjologicznym.

Dwubocznie symetryczne dzielą się na dwie bardzo wyraźnie różniące się w rozwoju embriologicznym grupy: pierwouste (Protostomia) i wtórouste - (Deuterostomia).

U pierwoustych otwór gębowy wykształca się w rozwoju embriologicznym z pragęby gastruli, układ nerwowy jest położony po stronie brzusznej, a układ krwionośny (serce) po stronie grzbietowej. U wtóroustych otwór gębowy wykształca się wtórnie, a pragęba zamienia się w odbyt, układ nerwowy leży po stronie grzbietowej, a serce po stronie brzusznej.

Na przekroju poprzecznym można powiedzieć, że są to zwierzęta odwrócone; popularnie mówi się na pierwouste - bezkręgowce, a na wtórouste - kręgowce, ale nie ma to uzasadnienia naukowego.

Ze zrozumiałych względów, uwagi o problemach w filogenezie zwierząt zostaną ograniczone do najważniejszych typów zarówno wśród pierwoustych, jak i wtóroustych.

W rozważaniach dotyczących monofiletyzmu spośród pierwoustych wzięto pod uwagę stawonogi (Arthropoda), najliczniejszy typ świata zwierząt, obejmujący ponad milion gatunków, w tym ponad 400000 gatunków chrząszczy (czyli co trzeci gatunek zwierzęcia jest chrząszczem). W typie stawonogów występują trzy grupy, z reguły w randze podtypów: skorupiaki (Crustacea), szczękoczułkowce (Chelicerata), obejmujące pajęczaki (Arachni- 
da), i trzecia grupa to stawonogi tchawkodyszne (Tracheata), w ramach której wyróżniamy owady (Insecta) i wije (Myriapoda).

Brak praktycznie danych tłumaczących, kiedy i w jaki sposób nastąpiła radiacja stawonogów, być może wydarzyło się to już we wczesnym kambrze bądź w prekambrze. Tak więc kwestia „monofiletyzm czy polifiletyzm?” jest pytaniem pierwszym przy rozpatrywaniu filogenezy stawonogów. Obok monofiletycznych poglądów na pochodzenie stawonogów istnieją również poglądy polifiletyczne. Pierwszymi zoologami, którzy uważali, że poszczególne grupy (podtypy) stawonogów mają niezależne pochodzenie, byli w latach 70. ubiegłego wieku Anderson i Manton. Taki pogląd ma daleko idące konsekwencje, bo likwiduje typ: stawonogi jako grupę polifiletyczną, a klasyfikacja wymaga, aby typ był jednostką monofiletyczną (ryc. 2).

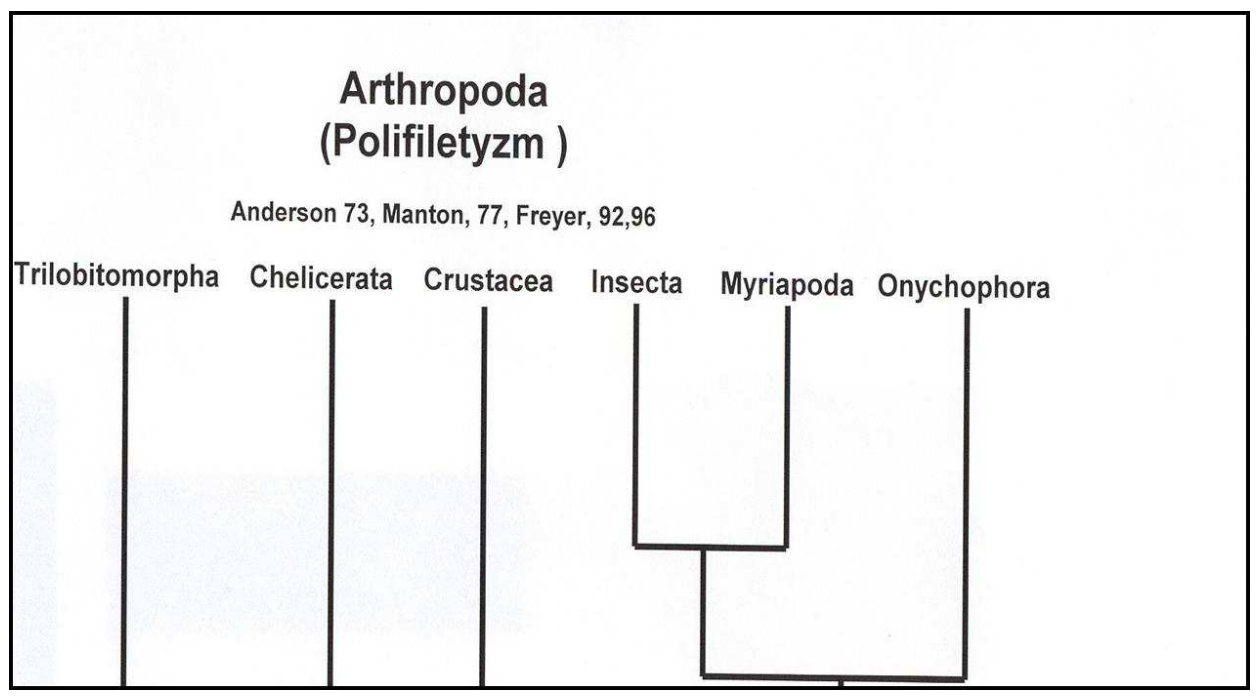

Ryc. 2. Polifiletyczne pochodzenie stawonogów według Andersona, Mantona i Freyera ${ }^{3}$

Monofiletyczne poglądy oparte są przede wszystkim na budowie narządów gębowych, a więc posiadaniu szczęk i żuwaczek, co jest wspólną cechą tchawkodysznych i skorupiaków (ryc. 3).

${ }^{3}$ Za: Cz. Błaszak, Tchawkodyszne - Tracheata, w: Zoologia, t. II, cz. 2: „Stawonogi - tchawkodyszne", red. Cz. Błaszak, Warszawa 2012. 


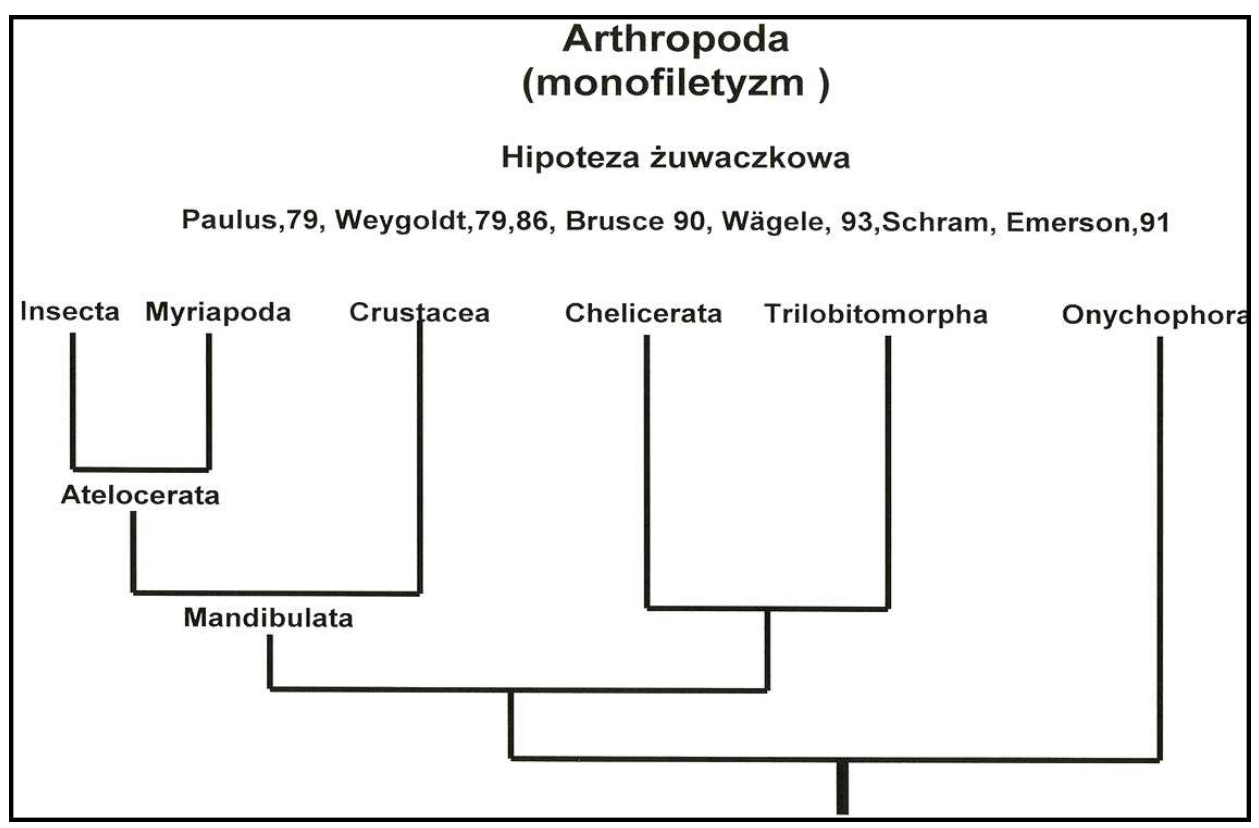

Ryc. 3. Monofiletyczne pochodzenie stawonogów według Paulusa, Weygoldta, Brusce’a, Wägele'a, Schrama i Emersona ${ }^{4}$

O ile te dwie grupy można byłoby wyprowadzać od jednego przodka, to trudno wyobrazić sobie przodka wspólnego dla obu tych grup (Mandibulata) i szczękoczułkowców, do których należą pajęczaki, a w poglądach monofiletycznych szczękoczułkowce są grupą siostrzaną do Mandibulata, czyli tych, co mają szczęki. Szczękoczułkowce bowiem od początku paleozoiku, a więc od kambru, nigdy nie miały głowy, i w związku z tym nie mają narządów gębowych (szczęk i żuwaczek). Otwór gębowy u pajęczaków znajduje się na rurkowatym rostrum albo jest szczeliną pomiędzy biodrami odnóży, jak np. u kosarzy. Kosarz, aby pobrać pokarm, musi na nim przysiąść, a pająk po zabiciu muchy musi wstrzyknąć enzymy trawiące, aby potem wessać rozpuszczone ciało ofiary, bo nie ma czym gryźć. Trudno sobie wyobrazić wspólnego przodka, gdyż, jak wiemy z badań paleontologicznych, nigdy nie znaleziono form, które nawiązywałyby zarówno do grupy Mandibulata (tchawkodyszne i skorupiaki), jak i jednocześnie do pajęczaków.

Sytuację komplikuje fakt, że istnieją również różne hipotezy (popierane przez badania molekularne) na temat tego, czy owady są grupą siostrzaną

\footnotetext{
${ }^{4}$ Za: ibidem.
} 
do skorupiaków (tworząc razem tzw. Pancrustacea), czy do wijów (tworząc tchawkodyszne - Tracheata). Na dodatek, z gromady owadów zostały usunięte tak zwane owady pierwotnie bezskrzydłe, które zarówno poprzez brak skrzydeł, ale również - jak pokazują wyniki badań - na poziomie molekularnym niewiele mają wspólnego $\mathrm{z}$ owadami uskrzydlonymi. $\mathrm{Z}$ tych owadów bezskrzydłych utworzono nowe gromady, które wraz z gromadą owadów właściwych (Insecta s.str.) zaliczone zostały do nadgromady sześcionogów (Hexapoda).

Rozważania w tym artykule dotyczą problemów z wyższymi jednostkami taksonomicznymi, takimi jak typy, działy. Jednakże podobne problemy występują $\mathrm{w}$ niższych jednostkach systematycznych, a przykładem niech będą roztocze - Acari („,podopieczni" autora tekstu), ogromna grupa pajęczaków mająca olbrzymie znaczenie epidemiologiczne i gospodarcze. Po badaniach molekularnych w 2010 roku roztocze zostały rozbite na dwie grupy zupełnie ze sobą niespokrewnione i niemające wspólnego przodka. Różnice te przejawiały się od zawsze w budowie anatomicznej. W ten sposób dotychczasowe roztocze były grupą sztuczną.

Sytuacja jest cały czas dynamiczna i mimo badań molekularnych dotyczących filogenezy stawonogów wciąż mamy wiele niejasności, a dowodem na to są różnorodne systematyki całego typu.

Rozważania dotyczące filogenezy stawonogów oparte były na założeniu, że pochodzą one od pierścienic zgodnie z hipotezą "jam ciała", z kolei w hipotezie "ecdyzonu” stawonogi (jako liniejące) nie mają nic wspólnego z pierścienicami. Jak z tego jasno wynika, w zależności od tego, jaką przyjmiemy hipotezę pochodzenia danej grupy (ale tylko hipotezę, bo pewności nie mamy żadnej), wychodzą nam różne spojrzenia na systematykę stawonogów, a więc rozszerzamy tylko ciąg znaków zapytania, które czekają na wyjaśnienie.

Typ: strunowce (Chordata) należy do filogenetycznej dużej grupy świata zwierząt wtóroustych (Deuterostomia), u których otwór gębowy w rozwoju powstaje wtórnie z końcowego odcinka prajelita, natomiast pragęba zamienia się w definitywny otwór odbytowy, odwrotnie niż u pierwoustych, czyli tak zwanych bezkręgowców.

Cechą charakterystyczną tego typu jest struna grzbietowa (chorda dorsalis). Następnymi ważnymi cechami diagnostycznymi, które stanowią również nowości ewolucyjne, są: centralny system nerwowy, rozwijający się z cewki nerwowej umiejscowionej po stronie grzbietowej nad struną grzbietową, a także przewód pokarmowy w przedniej części, poprzebijany szczelinami skrzelowymi i położony pomiędzy układem nerwowym a sercem, 
które leży po stronie brzusznej ciała. Najstarsze strunowce znane są już od kambru (Haikouella, Pikaia).

Najczęściej podawana jest tradycyjna klasyfikacja strunowców, zgodnie $\mathrm{z}$ którą takson ten $\mathrm{w}$ randze typu dzielony jest na trzy podtypy: osłonice (Tunicata), bezczaszkowce (Acrania) i kręgowce (Vertebrata). Obecnie zamiast podtypu kręgowców wyróżniany jest podtyp czaszkowców (Craniata), które zawierają kręgowce i śluzice. Zlikwidowanie podtypu kręgowce na korzyść czaszkowców wynikało stąd, że gromada śluzice nie ma kręgów, posiada tylko czaszkę, stąd nie mogła być zaliczana do kręgowców.

Pokrewieństwo tych trzech grup i ich wzajemne zależności w obrębie strunowców były przez lata tematem dyskusji i hipotez.

Podział strunowców (Chordata) i pokrewieństwo filogenetyczne występujących tam grup, a więc bezczaszkowców (Acrania), osłonic (Tunicata) i czaszkowców (Craniata), związane są z dwiema hipotezami (ryc. 4). Pierwszą, dzielącą strunowce na osłonice (Tunicata) i Notochordata (obejmującą bezczaszkowce - Acrania, i czaszkowce - Craniata). Osłonice charakteryzują się postanalnym ogonem mającym strunę grzbietową, cewką nerwową, gardzielą skrzelową z endostylem, natomiast Notochordata mają mięśnie ułożone w segmenty, segmentowaną celomę (somity), specyficzny układ krwionośny oraz strunę grzbietową występującą wzdłuż całego ciała.

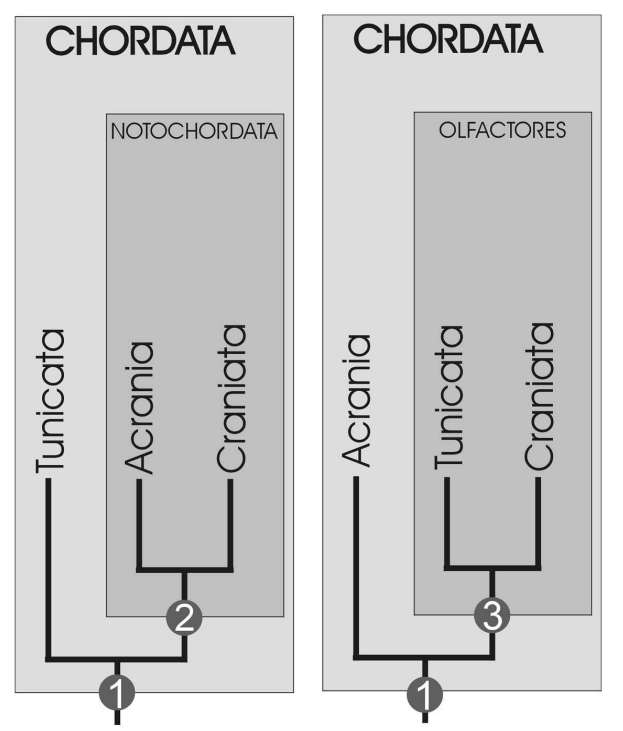

Ryc. 4. Hipotezy filogenezy strunowców ${ }^{5}$

${ }^{5}$ Za: Cz. Błaszak, M. Skoracki, Poddziat wtórouste - Deuterostomia, w: Zoologia, t. III, cz. 1: „Szkarłupnie - płazy”, red. Cz. Błaszak, Warszawa 2015. 
Druga hipoteza dzieli strunowce na bezczaszkowce i na grupę (klad) Olfactores, obejmujący osłonice (Tunicata) i czaszkowce (Craniata). Klad ten powstał na podstawie badań molekularnych, ale wiele cech morfologiczno-anatomicznych wspólnych dla osłonic i czaszkowców wskazuje na ich pokrewieństwo. Do takich cech należą: podobna budowa narządów węchowych, występowanie grzebienia nerwowego podczas rozwoju zarodkowego w okresie neurulacji (tworzenia się cewki nerwowej) czy rozszerzenie przedniej części cewki nerwowej.

Mimo że klad Olfactores powstał w skutek badań molekularnych, to jednak w literaturze dominuje pogląd, że bezczaszkowce (Acrania) i czaszkowce (Craniata) tworzą monofiletyczną grupę strunowców (Notochordata) o segmentowej budowie ciała (somity - mięśnie ułożone segmentalnie, co widać najlepiej u lancetnika i ryb). Cechami charakterystycznymi tej grupy są metameryczna budowa ciała i utrzymywanie się cech larwalnych, takich jak: struna grzbietowa, cewka nerwowa, a u osobników dorosłych - postanalny ogon.

Jak widać z tych rozważań, nie ma żadnych przekonujących dowodów na to, że jakakolwiek hipoteza dotycząca podziału strunowców jest hipotezą pewną. Ponadto zwraca uwagę fakt, że badania molekularne nie muszą mieć przewagi nad badaniem występowania cech anatomicznych.

W ewolucji czaszkowców bardzo ważnym momentem było pojawienie się szczęk, które wspierają otwór gębowy. Pojawienie się szczęk u wczesnych ryb i ogromne zróżnicowanie ich budowy i funkcji umożliwiło, w niespotykanej wcześniej skali, rozwój możliwości odżywiania się. Pojawienie się szczęk było wydarzeniem o kluczowym znaczeniu w sukcesie ewolucyjnym kręgowców. Nowe sposoby odżywiania się sprzyjały zajmowaniu nowych habitatów, najpierw w środowiskach wodnych, a następnie lądowych.

Sposób wyodrębnienia się szczęk nie jest pewny. Klasyczna hipoteza o powstaniu szczęk z przekształconych łuków skrzelowych jest już kwestionowana. Powodem jest między innymi brak kopalnych przykładów bezszczękowców (Ostrakodermi), które miałyby struktury wskazujące na przekształcenie skrzeli w szczęki. Zagadnienie powstania szczęk u kręgowców pozostaje problemem otwartym. Pewnym wydaje się, że szczęki pojawiły się stosunkowo nagle, wraz z pojawianiem się w sylurze szczękowych ryb tarczowców (Placodermi) i fałdopłetwych (Acanthodii). Co jest godne podkreślenia, oba te szczękowe taksony do końca dewonu współwystępowały z Ostracodermi - bezszczękowcami, które są uważane za przodków kręgowców szczękowych. 
Drugą ważną i nową cechą u kręgowców szczękowych są parzyste płetwy. Pojawienie się szczęk i płetw parzystych nie odbywało się równolegle, znane są bowiem kopalne bezszczękowce z płetwami parzystymi. Płetwy parzyste kręgowców szczękowych mogły ewoluować z parzystych fałdów skóry, która znajdowała się wzdłuż brzuszno-bocznej ściany ciała. Podobnie jednak jak w przypadku pochodzenia szczęk, proces powstawania płetw parzystych nie jest dokładnie znany.

Silna radiacja kręgowców szczękowych, będących drapieżnikami, spowodowała stopniowe wymieranie i zanikanie bezszczękowych ostrakoderm.

Prawdopodobnie na początku syluru, około 345 milionów lat temu, pojawiło się pięć grup kręgowców szczękowych: wymarłe ryby pancerne (Placodermi), ryby chrzęstnoszkieletowe (Chondrichthyes), wymarłe ryby fałdopłetwe (Acanthodii), ryby o szkielecie kostnym - promieniopłetwe (Actinopterygii) i ryby mięśniopłetwe (Sarcopterygii) (ryc. 5).

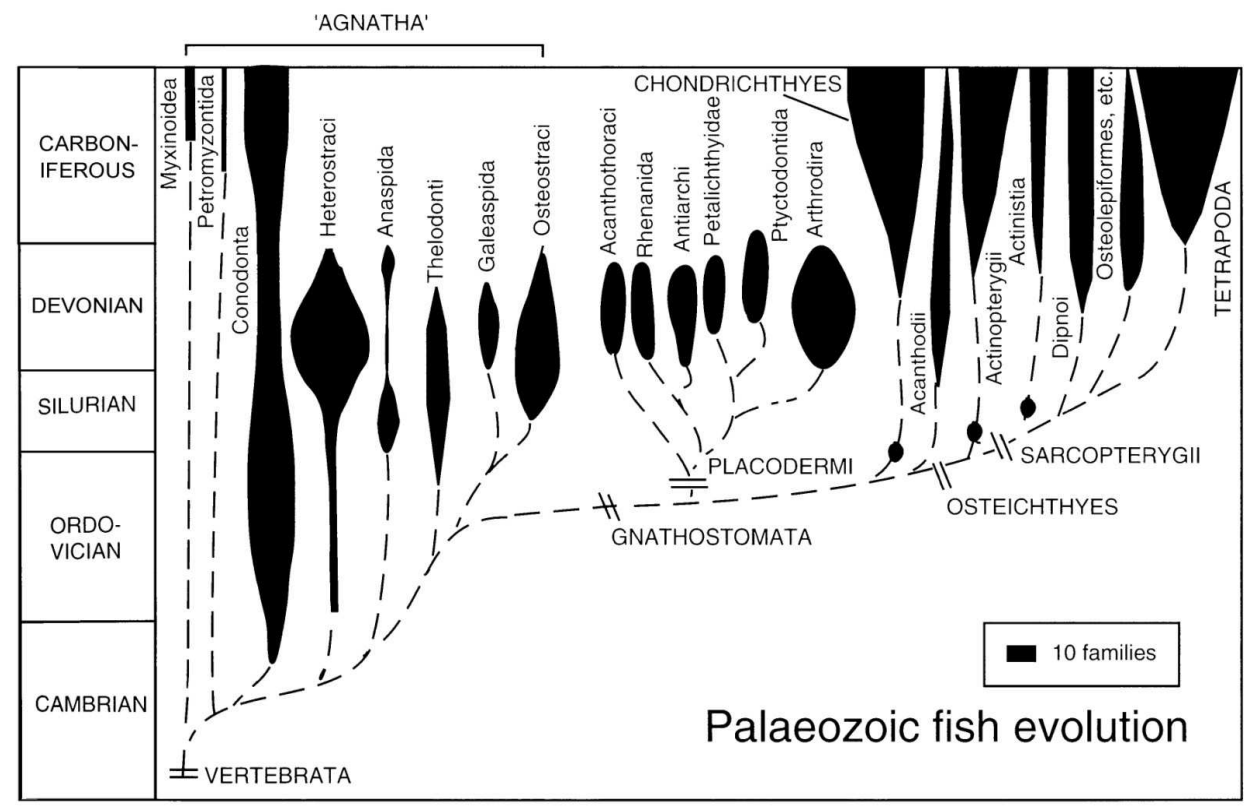

Ryc. 5. Ewolucja ryb paleozoicznych prowadząca do kręgowców lądowych Tetrapoda6

${ }^{6}$ M.J. Benton, Vertebrate Palaeontology (za zgodą John Wiley and Sons), za: M. Rybacki, Kręgowce lądowe - Tetrapoda, w: Zoologia, t. III, cz. 1: „Szkarłupnie - płazy”, red. Cz. Błaszak, Warszawa 2015. 
Zwraca uwagę fakt, że ryby, jako gromada, nie istnieją, gdyż poszczególne wyżej wymienione grupy ryb są gromadami, a dotychczasowa gromada „ryby” jest grupą polifiletyczną, czyli w praktyce nie ma takiej jednostki taksonomicznej jak ryby (Pisces). Ryby nie tworzą więc istotnej grupy filogenetycznej, a wyróżnia się ją tylko ze względu na wodne środowisko, w którym żyją.

Oprócz tych aktualnie żyjących gromad ryb szczękowych (chrzęstnoszkieletowe, promieniopłetwe i mięśniopłetwe), do kręgowców szczękowych należy grupa czworonogów lądowych (Tetrapoda), obejmująca następujące gromady: płazy, gady, ptaki i ssaki.

Z wyżej wymienionych gromad wszystkie gromady ryb szczękowych i płazy (jako organizmy ziemno-wodne) tworzą grupę bezowodniowców (Anamnia), a więc organizmów, które nie wytwarzają w rozwoju embrionalnym błon płodowych. Jaja bezowodniowców pokryte są galaretowatą osłonką, a ich zarodki są zamknięte i chronione błonami produkowanymi w przewodach płciowych samicy. U bezowodniowców po okresie rozwoju zarodkowego zarodek rozrywa osłonki jajowe i rozwija się dalej w wodzie jako stadium larwalne.

Gromada: płazy (Amphibia) to organizmy dwuśrodowiskowe (ląd i woda) i zmiennocieplne. Płazy są czworonożnymi kręgowcami, które jako pierwsze zaadaptowały się do życia na lądzie. Nadal jednak są ściśle związane ze środowiskiem wodnym lub wilgotnym, w którym $\mathrm{z}$ reguły następuje ich rozwój.

Współczesne płazy (Lissamphibia) dzielą się na trzy morfologicznie wyraźnie odrębne grupy $\mathrm{w}$ randze rzędów, pomiędzy którymi nie ma form pośrednich: płazy ogoniaste $($ Caudata $=$ Urodela), płazy bezogonowe (Anu$\mathrm{ra}=$ Salientia $)$ i płazy beznogie (Gymnophiona $=$ Apoda).

Obecnie jedną $\mathrm{z}$ największych kontrowersji w dyskusji nad pochodzeniem płazów budzi kwestia, czy płazy współczesne (Lissamphibia) są grupą monofiletyczną, czy polifiletyczną, i czy wywodzą się od Temnospondyli, czy od Lepospondyli (ryc. 6).

Temnospondyli to grupa polifiletyczna, która wraz ze współczesnymi płazami tworzy grupę płazokształtnych (Batrachomorpha), natomiast Lepospondyli są grupą siostrzaną Reptiliomorpha, z których wywodzą się gady, czyli owodniowce, obejmujące jeszcze ptaki i ssaki.

Obecnie istnieją trzy hipotezy wyjaśniające pochodzenie płazów współczesnych (Lissamphibia) (ryc. 6). Pierwsza hipoteza zakłada, że Lissamphibia są monofiletyczne i pochodzą od Temnospondyli. Druga hipoteza zakłada, że Lissamphibia są monofiletyczne, ale pochodzą od Lepospondyli, 
a więc od grupy, która jest związana z gadokształtnymi Reptiliomorpha. Trzecia hipoteza zakłada polifiletyzm płazów - płazy beznogie $($ Apoda $=$ Gymnophiona) powstałyby $\mathrm{z}$ Lepospondyli (nawiązywałyby do gadokształtnych przodków), natomiast ogoniaste (Caudata) i bezogonowe (Anura) z Temnospondyli 7 .

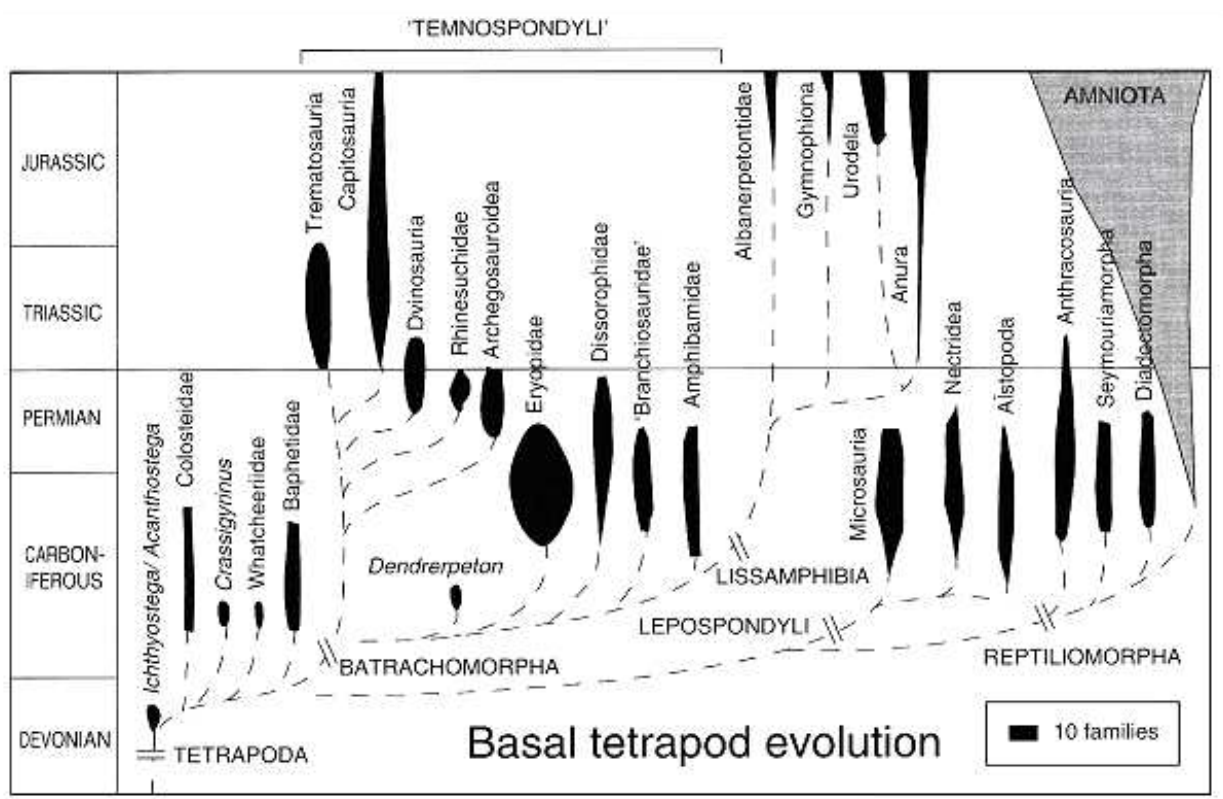

Ryc. 6. Ewolucja wyjściowych grup Tetrapoda, ukazująca ich znane grupy kopalne w ujęciu geologicznym (skala pionowa), proponowane pokrewieństwo (linie przerywane) oraz ich względną różnorodność (szerokość „balonów”) 8

Obecny stopień zaawansowania dyskusji na temat pochodzenia Tetrapoda oraz rosnąca liczba aktualnych prac popierających wszystkie trzy hipotezy o pochodzeniu płazów wskazują na to, że problem ten jeszcze długo nie zostanie w pełni rozwiązany.

Filogeneza płazów jest przykładem, że mimo zaawansowanych technik molekularnych, anatomicznych i znalezisk paleontologicznych, mamy trzy hipotezy, które można praktycznie dowolnie przyjmować, bo każda z nich ma swoje racje.

7 M. Rybacki, Poglądy na pochodzenie płazów wspótczesnych Lissamphibia; w: Zoologia, t. III, cz. 1: „Szkarłupnie - płazy”, red. Cz. Błaszak, Warszawa 2015, s. 471-665.

${ }^{8}$ M.J. Benton, Vertebrate Palaeontology (za zgodą John Wiley and Sons), za: M. Rybacki, op. cit. 
Niezwykle ważnym momentem $\mathrm{w}$ ewolucji było pojawienie się błon płodowych, służących przystosowaniu do lądowego trybu życia. Bezpośrednią błoną otaczającą zarodek jest owodnia (amnion) wypełniona płynem owodniowym, który zapewnia zarodkowi stabilne środowisko. Do owodniowców należą następujące gromady: gady, ptaki i ssaki.

Filogenezę ptaków tylko zasygnalizuję, gdyż jest tak wiele kontrowersji w badaniu pochodzenia ptaków, że zajęłoby to przynajmniej kilkadziesiąt stron i ostatecznie niczego by nie wyjaśniło. $W$ taksonomii filogenetycznej ptaki znajdują się w obrębie dinozaurów (klad teropody), jako grupa siostrzana do kladu krokodyli. Tak więc krokodyle i ptaki są jedynymi aktualnie żyjącymi gadami naczelnymi. Kontrowersje dotyczą już hipotez, czy ptaki pochodzą od dinozaurów ptasiomiednicowych, czy od gadziomiednicowych. Inne hipotezy mówią, że ptaki nie są dinozaurami, tylko pochodzą bezpośrednio od archozaurów.

Aby zaoszczędzić czytelnikowi rozważań na temat pochodzenia skowronków, słowików i innych ptaszków umilających nam życie, autor pozwoli sobie zakończyć na tym uwagi dotyczące pochodzenia tych „opierzonych dinozaurów".

Filogeneza ssaków, ze względu na ograniczenia objętościowe artykułu, zostanie tu potraktowana wybiórczo, chociażby dlatego że w 2014 roku ukazała się $\mathrm{W}$ języku polskim książka znakomitego polskiego zoologa-palentologa, profesor Zofii Kielan-Jaworowskiej, pod tytułem $W$ poszukiwaniu wczesnych ssaków ${ }^{9}$, będąca tłumaczeniem angielskojęzycznej edycji In pursuit of Early Mammals wydanej przez Indiana University Press.

Jak niezwykle ważne są nowe techniki badań i nowe znaleziska paleontologiczne, niech świadczy porównanie dwóch prac Z. Kielan-Jaworowskiej: pierwszej, zatytułowanej Pochodzenie ssaków: odkrycia i kontrowersje i opublikowanej w czasopiśmie „Kosmos” w 1996 roku10, a także tej wyżej wymienionej z 2014 roku. We wcześniejszej pracy Kielan-Jaworowska pisze, że w filogenezie ssaków najważniejsze jest ustalenia pozycji tak zwanych wieloguzkowców (Multituberculata) - wymarłych ssaków o charakterystycznych zębach. To pozwoli stwierdzić, czy ssaki są monofiletyczne, czy polifiletyczne. Jeśliby wieloguzkowce wyodrębniłyby się z innej grupy cynodontów niż pozostałe ssaki, to mielibyśmy do czynienia $\mathrm{z}$ difiletyzmem $\mathrm{w}$ pochodzeniu ssaków, a więc ssaki nie byłyby monofiletyczne. Również pozycja systematyczna stekowców została uznana w tym artykule za zagadnienie niejasne. 2014.

${ }^{9}$ Z. Kielan-Jaworowska, W poszukiwaniu wczesnych ssaków. Ssaki ery dinozaurów, Warszawa

10 Eadem, Pochodzenie ssaków: odkrycia i kontrowersje, „Kosmos” 1996, nr 4(45), s. 603-622. 
Autorka stwierdza, że przeważa tendencja, aby nazwę „ssaki właściwe” stosować tylko dla wspólnego przodka ssaków łożyskowych i torbaczy, a stekowce traktować jako oddzielną grupę. W podręczniku z 2014 roku wieloguzkowce są już umieszczone przy podstawie ssaków (Theria), a stekowce są uznane za grupę siostrzaną ssaków właściwych. Przedmowę do książki z 2014 roku napisał amerykański paleontolog, współautor wielu prac z Zofią Kielan-Jaworowską, Richard L. Cifelli. Stwierdził on tam, iż „odkrycia omawiane na kartach tej książki, choć znaczące, przedstawiają jedynie z grubsza rozpoznane wysepki na ciągle mało znanym morzu. Przyszłe badania ssaków mezozoicznych mogą przynieść zaskakujące wyniki. Niewykluczone, że pojawią się okazy, które zmienią naszą obowiązującą od dziesięcioleci wiedzę na ich temat"11. To pokazuje, jak nasza wiedza jest dynamicznie uzupełniana, ale wskazuje również, jak mało jeszcze wiemy o filogenezie świata zwierząt.

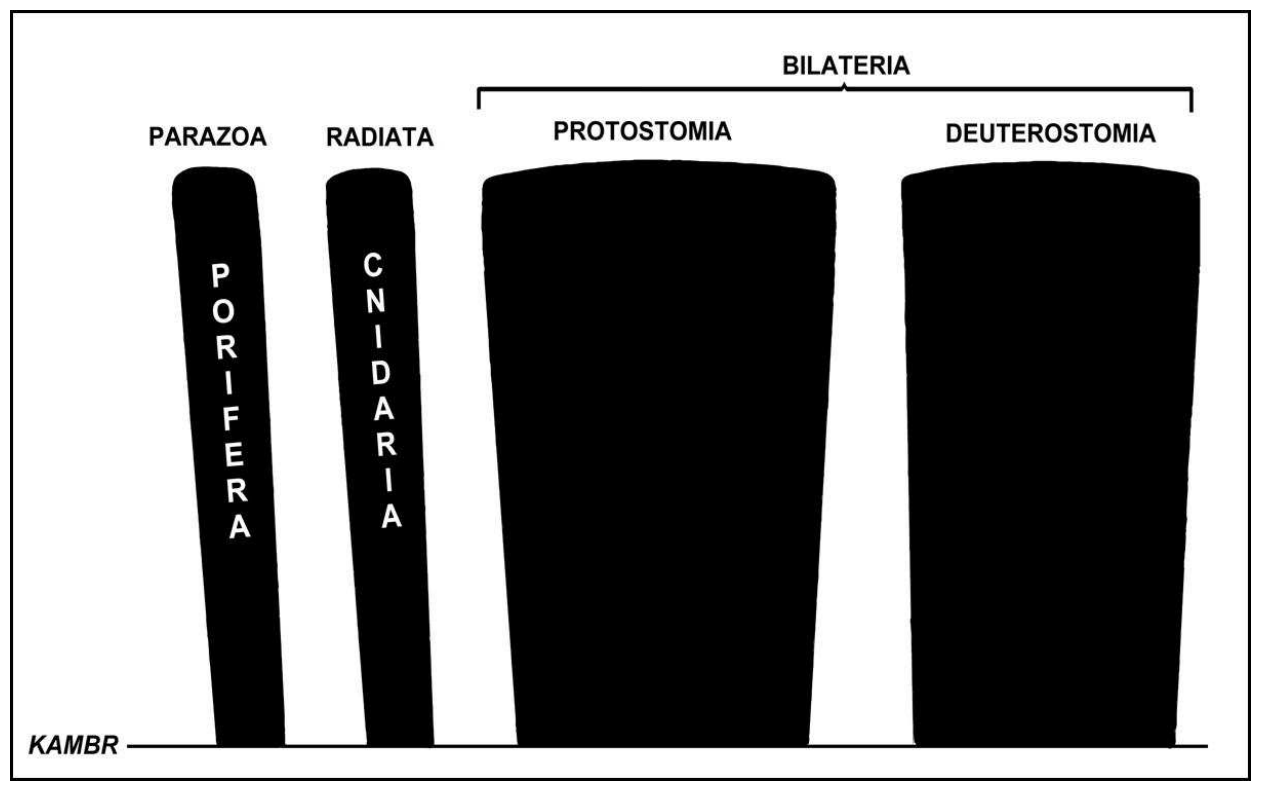

Ryc. 7. Filogeneza punktualistyczna pokazująca możliwość ewolucji niezależnej takich grup, jak Parazoa, Radiata, Protostomia i Deuterostomia (źródło: Autor)

Tę wypowiedź odnieść można do całej filogenezy świata zwierząt. Dodałbym jednocześnie, że nie ma grupy świata zwierząt, w której nie byłoby problemów dotyczących filogenezy. Stwierdzenie moje opieram na kilku-

${ }^{11}$ Eadem, W poszukiwaniu..., op. cit., s. XI (przedmowa). 
dziesięcioletnim doświadczeniu jako osoby prowadzącej zarówno wykłady z zoologii, jak i z filogenezy świata zwierząt.

Podsumowując te krótkie rozważania dotyczące meandrów w filogenezie świata zwierząt, należy zastanowić się, jak winno wyglądać drzewo filogenetyczne - czy rzeczywiście drzewo typu baobabu, z odchodzącymi gałązkami i potężnymi konarami (ryc. 1)? Czy te dolne gałązki winny tak nisko wyrastać i czy nie powinny być oddzielnymi krzaczkami? To pytanie należy postawić, ponieważ już wielokrotnie formułowane były punktualistyczne hipotezy filogenetyczne dotyczące zwierząt (próbę pokazania poglądu punktualistycznego obrazuje ryc. 7).

Dowodem na to, że również $\mathrm{w}$ drzewie filogenetycznym wszystkich organizmów żywych jest bardzo wiele niejasności, jest praca W. Forda Doolittle'a z 2000 roku pod tytułem Uprooting the Tree of Life, wydana w "Scientific American". W tym samym roku została ona przetłumaczona na język polski i opublikowana w "Świecie Nauki" pod znamiennym tytułem Filogeneza na rozstajach. Autor pisze tam o chwiejącym się drzewie filogenetycznym, ukazując drzewo monofiletyczne i polifiletyczne (ryc. 8, 9).

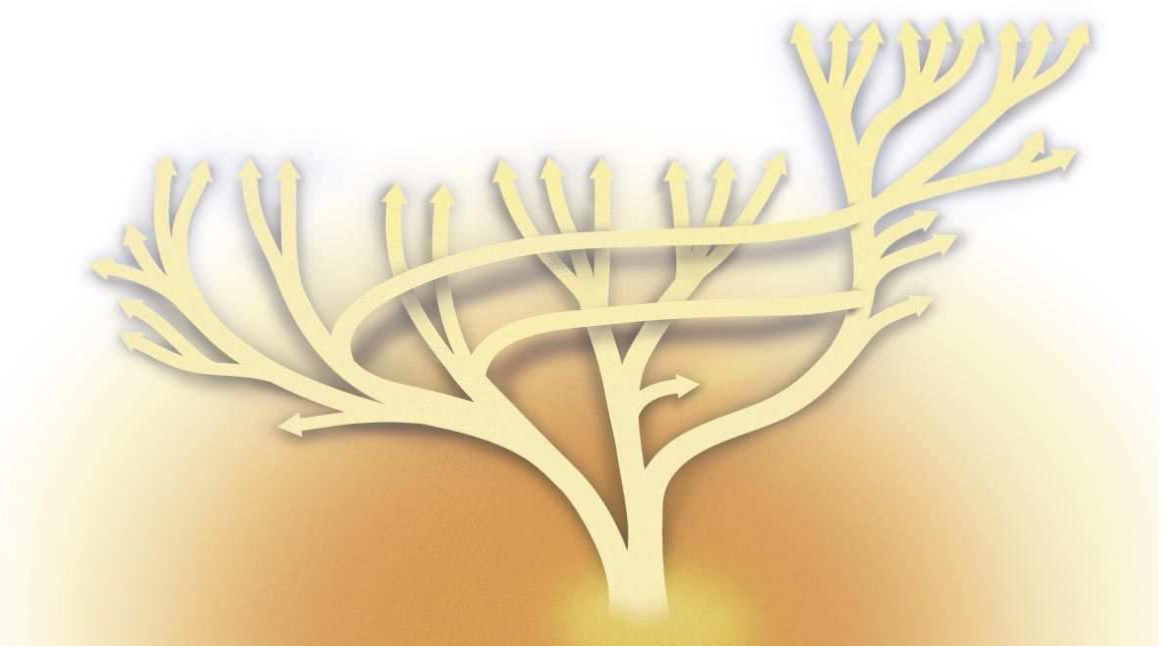

Ryc. 8. Monofiletyzm świata organicznego obejmujący zarówno cesarstwo prokariotyczne, jak i cesarstwo eukariotyczne (wystające gałązki po prawej stronie) ${ }^{12}$

12 Za: W.F. Doolittle, Filogeneza na rozstajach, „Świat Nauki” 2000, nr 5(105); oryg. W.F. Doolittle, Uprooting the tree of life, "Scientific American” 2000, vol. 282, nr 2 (ilustracja zmieniona). 


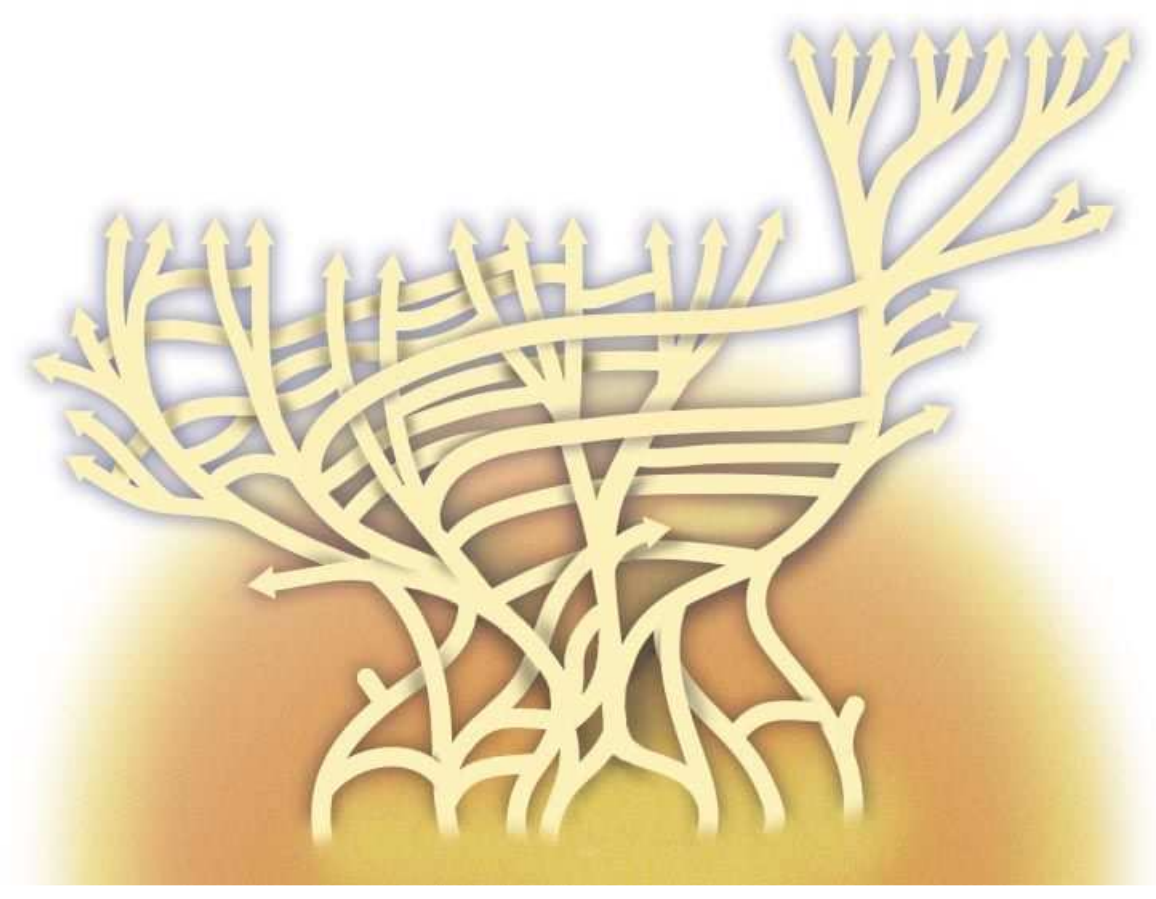

Ryc. 9. Polifiletyzm świata organicznego obejmujący zarówno cesarstwo Prokariotyczne, jak i cesarstwo eukariotyczne ${ }^{13}$

U postawy drzewa monofiletycznego autor umieszcza pojedynczą komórkę jako protoplastę dla wszystkich organizmów żywych, a w ujęciu polifiletycznym jest wiele komórek będących protoplastami dla poszczególnych gałęzi drzewa filogenetycznego.

Ostatnią ryciną jest bardzo charakterystyczne drzewo filogenetyczne wszystkich organizmów eukariotycznych (ryc. 10) w postaci płatków kwiatu, gdzie poszczególne płatki to przede wszystkim domeny obejmujące "pierwotniaki" (Excavata, Discicristata, Stramenopile, Rhizaria, Alveolata i Amebozoa). Jednym z płatków jest domena Archaeplastida, w której znajdują się rośliny, ostatnim zaś domena Opisthokonta, w której pod postacią jednej kreseczki mamy zwierzęta (Animals), w bardzo bliskim pokrewieństwie do grzybów.

${ }^{13}$ Za: ibidem (ilustracja zmieniona). 


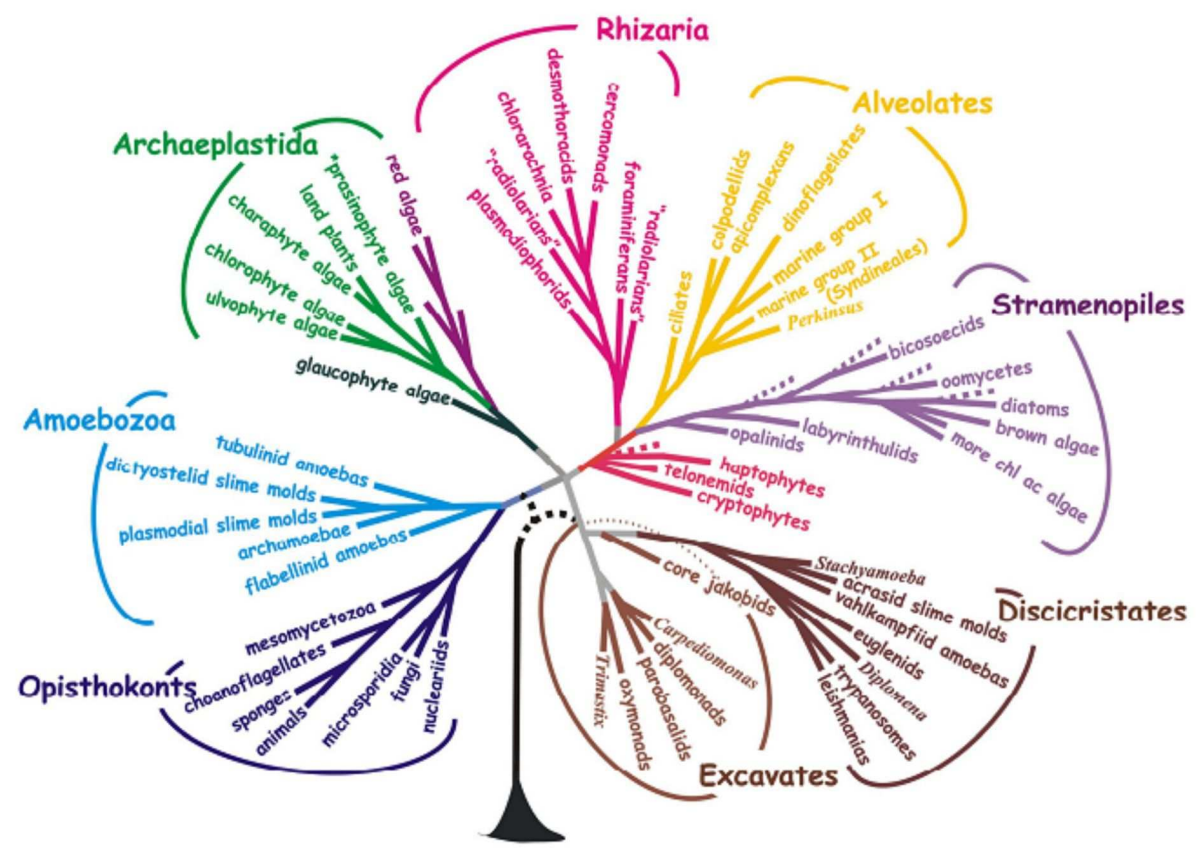

Ryc. 10. Konsensus w filogenezie dużych grup organizmów eukariotycznych w oparciu o badania molekularne i ultrastrukturalne ${ }^{14}$

Właśnie z filogenezą (jej meandrami i kontrowersjami) tejże prostej, gładkiej i nierozgałęziającej się „kreseczki” próbowałem zapoznać Czytelnika. Jak pięknie i prosto wygląda taka gałązka w filogenezie cesarstwa organizmów eukariotycznych. Mam nadzieję, że Czytelnik zrozumie autora, który wchodząc $\mathrm{w}$ tak nieprawdopodobnie trudny temat, mógłby powiedzieć, że pisanie o filogenezie można byłoby przyrównać do cierpień młodego Wertera (który jednak cierpiał $\mathrm{z}$ innego powodu).

Na zakończenie jestem winny wyjaśnienie początku tytułu mego artykułu: „Odwieczność okiem przyrodnika...” W prowadzeniu przez meandry filogenezy świata zwierząt i poszukiwaniu przodków dla wybranych grup taksonomicznych doszliśmy do ryciny numer 10, która wskazuje, że wszystko zbiega się w centralnym punkcie, a więc w tym, co W.F. Doolittle nazwał

14 Za: S.L. Baldauf, The deep roots of eukaryotes, "Science” 2003, nr 300; według: eadem, An overview of the phylogeny and diversity of eukaryotes, "Journal of Systematics and Evolution" 2008, vol. 46, nr 3. Pozwolenie na publikację ryciny otrzymałem od znakomitego biologa molekularnego i filogenetyka, pani prof. S.L. Baldauf z Department of Evolution, Genomics and Systematics, Evolutionary Biology Centre, University of Uppsala (Szwecja), której składam serdeczne podziękowanie. 
protoplastą wszystkich żywych organizmów. To właśnie tłumaczyłoby początek tytułu: od "teraz" do "prakomórki", od której wszystko się zaczęło.

\section{Primordiality from the Naturalist's Point of View. The Intricacies of the Animal Phylogeny}

\section{Summary}

In the present review, an attempt to define the animal kingdom against a background of other kingdoms in the domain of eukaryotic organisms is presented, showing the common features linking the animal kingdom with the kingdom of fungi. The animals were clearly separated from other kingdoms through two unique systems characteristic of them: nervous and muscular. The matter is complicated by the fact that in the four types of the animal kingdom (Porifera, Placozoa) the nervous and muscular systems are absent. Therefore, zoologists proposed the name Metazoa - multicellular animal - for the animal kingdom. The main problematic issues of monophyly based on selected phylogenetic groups and phyla are discussed. In addition to the phylogenetic tree (based on monophyly) the punctuated equilibrium was established for four independent groups: Porifera, Cnidaria, Protostomia, Deuterostomia. Finally, the position of the animal kingdom in the monophyletic point of view and against a background of all other organisms is presented.

Słowa kluczowe: filogeneza, zwierzęta, kontrowersje

Keywords: phylogeny, animals, intricacies

DOI: $10.14746 /$ cbes.2016.15.1 